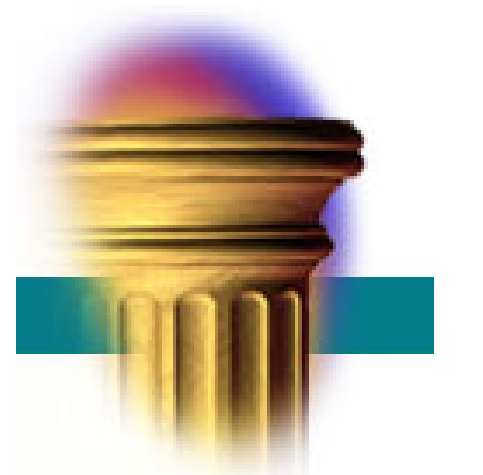

0

of

0

ש

4

E

a

ש
Debit Card and Cash Usage:

A Cross-Country Analysis

Gene Amromin and Sujit Chakravorti 


\title{
Debit Card and Cash Usage: A Cross-Country Analysis
}

\author{
Gene Amromin and Sujit Chakravorti
}

March 2007

\begin{abstract}
During the last decade, debit card transactions grew rapidly in most advanced countries. While check usage declined and has almost disappeared in some countries, the stock of currency in circulation has not declined as fast. We use panel estimation techniques to analyze the change in transactional demand for cash resulting from greater usage of debit cards in 13 countries from 1988 to 2003 . We are able to disentangle cash's store of value function from its payment function by separating cash into three denomination categories. We find that the demand for low denomination notes and coins decreases as debit card usage increases because merchants need to make less change for customer purchases. On the other hand, the demand for high denomination notes is generally less affected suggesting that these denomination notes are also used for nontransactional purposes.
\end{abstract}

Key words: payment networks, money demand, consumer choice, technological infrastructure JEL Classifications: D23, E41, G21

Amromin can be reached at gamromin@,frbchi.org and Chakravorti can be reached at sujit.chakravorti@chi.frb.org. We thank Dick Porter for helpful discussions regarding currency usage. We thank Erin Davis, Tiffany Gates, Victor Lubasi, Tim McHugh, Sue Parren, and Stan Rabinovich for excellent research assistance. The views expressed are those of the authors and do not represent the views of the Federal Reserve Bank of Chicago or the Federal Reserve System. 
In this article, we study the factors influencing the adoption of electronic payment alternatives such as debit cards and their impact on cash usage. This area of research is relevant for several reasons. First, greater usage of cash substitutes affects how much cash the central bank should supply. Economists continue to debate the implications of a possible reduction in currency demand for monetary policy (Buiter, 2005; Chakravorti, 2006; Freedman, 2000, Friedman, 1999; Goodhart, 2000; Kroszner, 2003; Woodford, 2000). One consequence of lower demand for cash is a decrease in seigniorage revenue. Humphrey, Kaloudis, and Øwre (2004) view outstanding currency as interest-free loans and if there is a significant reduction in the quantity of cash in circulation resulting from the use of alternative payment instruments, the potential loan repayment would be very large. Second, some economists have suggested social welfare would improve if fewer cash transactions occurred (De Grauwe, Buyst, and Rinaldi 2000; Van Hove, 2004a). However, whether the number of cash transaction has indeed declined in recent years proved to be a tricky empirical question, owing to difficulties in separating cash's payment function from its store of value function. Third, the relationship between the willingness of consumers and merchants to adopt non-cash payment alternatives and the pricing of those payment instruments has attracted considerable research attention (Chakravorti and McHugh, 2002; Humphrey, Pulley, and Vesala, 1996; Markose and Loke, 2002; Rochet and Tirole, 2003). Any debate on the pricing of payment instruments should start with studying the factors influencing the migration from cash to other payment media. Our analysis provides a necessary first step to address these issues.

We discuss payment trends in thirteen countries-Austria, Belgium, Canada, Finland, France, Germany, Italy, Japan, the Netherlands, Sweden, Switzerland, the United Kingdom, and the United States - from 1988 to 2003. We find that in most countries, debit card usage has increased significantly and check usage continues to decrease or has almost disappeared. 
However, the aggregate demand for cash has not fallen drastically with widespread adoption of non-cash payment instruments. Unlike other payment instruments, cash serves as a universally accessible store of value in addition to being a payment medium. Thus, any analysis of the impact of cash alternatives must first disentangle the two competing functions of cash. This task is complicated further by the unique anonymity feature of cash, which is valued highly by those trying to avoid detection by the public authorities. Cash transactions are more difficult to trace to the transactors because it can be used multiple times without third-party intervention unlike payment cards where each transaction is converted to good funds. Consequently, cash has an enduring appeal for facilitating illicit transactions, as well as for storing ill-gotten (or, at least, untaxed) wealth (Drehmann, Goodhart, and Krueger, 2002).

Our analysis differs from the existing literature in the following ways. First, we decompose cash demand by currency denomination type to better identify the transactional motive for cash holdings. Denominations larger than those commonly dispensed by a country's ATMs are posited to be better suited for store of value purposes. Although ATM-dispensed banknotes form the bulk of transactional currency demand by volume, analysis of fluctuations in such "medium-value" denominations presents a number of empirical challenges. In particular, the rapid growth of ATM networks over the past two decades had a theoretically ambiguous effect on observed quantities of medium-value notes in circulation. On the one hand, more ATMs may have reduced the stock of such notes by lowering transaction costs of obtaining them. On the other hand, the need to stock a larger number of ATMs with currency to be dispensed may have generated the opposite effect. Consequently, medium-value banknotes represent a noisy data source for establishing a relationship between the growth of alternative payment instruments and cash demand. In contrast, the demand for smaller denomination notes and coins is unaffected by secular changes in ATM networks. Rather, we argue that these forms 
of cash capture the demand by merchants and other receivers of cash to make change for purchases. Since change is given only in the case of cash transactions, changes in the stock of small notes and coins provide a better gauge of fluctuations in transactional demand for currency. Although other papers employed currency decomposition by denomination (see e.g. Drehmann, Goodhart, and Krueger, 2002; Fischer, Köhler, and Seitz, 2004; and Porter and Judson, 1996), we believe that ours is the first paper to attempt identification of cash demand through its "trickling down" to change-making small denomination notes and coins.

Second, we employ different econometric techniques than those commonly used in this literature to address strong serial correlation that is present when analyzing annual cross-country payments data. We show that results depend importantly on the choice of the econometric model. Finally, our data covers the time period of rapid growth in debit card usage in almost all countries in the sample. That is, unlike many of the previous studies, we are able to analyze the effect of accelerating and decelerating changes in debit card usage on cash demand.

Providers of debit card services must convince both consumers and merchants to use them over existing and emerging payment alternatives. We find that enabling consumers to use debit cards is not sufficient to increase their usage. The recent payments literature using a twosided market framework highlights the importance of having both sides_-payors and payees_on board (Armstrong, 2004; Rochet and Tirole, 2003). Consumers, for the most part unknowingly, added debit cards to their wallets because they were mainly seen as devices to access cash and make deposits at automated teller machines (ATMs) that became popular almost a decade before widespread debit card usage. They were unable to use their cards to make purchases until merchants adopted POS debit terminals. While adoption of payments technology by end-users does not guarantee widespread usage, in the case of debit cards, we show that adoption of debit 
card terminals by merchants was the critical step that led to the explosive growth in debit card transactions.

Finally, we study the impact of debit card usage on the stock of currency and coin outstanding. The impact of debit cards varies by currency denomination category. We find that larger denomination notes are affected by the short-term interest rate but not by the adoption of POS debit card terminals. However, both debit card infrastructure and financial institution branch infrastructure significantly affects the demand for small denomination notes and coins whereas the short-term interest rate has little effect. This result supports the hypothesis that small denomination notes and coins are required to make change for purchases when cash is used. If cash is not used, the demand for change and consequently the demand for small denomination notes and coins both decrease. Because financial institutions are the main distributors of small denomination notes and coins, less debit card usage requires a more extensive branch network to distribute and collect small denomination notes and coins.

This article is organized as follows. In section 1, we discuss payment trends across the countries in our sample. In section 2, we review the literature that analyzes the impact of electronic payment alternatives on cash. We discuss the data in section 3 and analyze the key factors driving the adoption of debit cards in section 4. In section 5, we focus on the relationship between the adoption of debit cards and changes in the stock of cash, broken by denomination categories. We offer some concluding remarks in section 6 .

\section{Cross-Country Payment Trend Comparisons}

While there are major differences in banking and regulatory structures along with differences in cultural attitudes toward payments between countries in our sample, certain common payment trends exist. First, debit card usage grew rapidly during the 1990 s in most 
countries in our sample. In Figure 1, we plot debit card transactions over time by country. In 1988, all countries except for Finland had less than 10 debit card transactions per person per year. By 2004, all countries except Japan had more than 10 transactions per person per year and several had more than 60 . The increase in debit card transactions suggests that the net benefits of using debit cards have increased vis-à-vis other payment instruments for consumers and merchants (assuming that the total number of transactions is growing at a slower rate than debit card transactions.)

The second common trend is that check usage continues to decrease in most countries and has disappeared in many countries. There are eight countries where on average less than two checks per person were written in 2004 (see Table 1). Even in countries with a relatively high number of check transactions such as Canada (43 checks/person), France (66 checks/person), the United Kingdom (35 checks/person), and the United States (119 checks/person), check usage continues to decline. Some studies find that debit cards have substituted for check transactions (Borzekowski and Kiser, 2006 and Klee, 2006).

Third, cash has not disappeared from these countries although several cash substitutes exist. ${ }^{1}$ While general-purpose stored-value cards have not been widely adopted, other generalpurpose payment instruments, e.g. credit and debit cards, can now be used for transactions in environments that were until recently "cash only."2 Mass transit and fast food restaurants represent just two of the more ubiquitous industries where such switch took place. Some surveys of merchants and consumers suggest that cash demand for transactions is decreasing in many

\footnotetext{
${ }^{1}$ Originally, checks were a cash substitute. Humphrey (2004) reports that in addition to replacing cash transactions for consumer payments, employee disbursements, and smaller-value business purchases shortly after the Civil War, checks were used until 1915 for large-value business transactions and interbank transfers in the United States.

${ }^{2}$ For more on the lack of widespread acceptance of general-purpose stored value, see Chakravorti (2004) and Van Hove (2004b). More recently, prepaid cards have become popular for certain applications such as gift giving and disbursement of payroll and government benefits in the United States. For more details, see Chakravorti and Lubasi (2006).
} 
countries (American Bankers Association and Dove Consulting, 2005; Jyrkönen, 2004; Stix, 2003).

One metric to compare cash transactions across countries is the total per capita annual non-cash transactions. Generally, greater use of non-cash payment instruments indicates a lesser reliance on cash as a payment medium. ${ }^{3}$ The number of non-cash transactions per capita in 2004 (Table 1) ranges from 36 for Japan to 288 for the United States. Furthermore, non-cash transactions have increased between 2001 and 2004 for all countries in our sample, suggesting a reduction in cash transactions over time within a country.

Two measures of overall cash demand are cash holdings per capita and cash outstanding to GDP ratio. However, these two measures are unable to distinguish between cash's store of value and payment functions. In Table 2, we compare countries by their per capita currency holdings (in US dollars) and their ratio of the stock of currency to GDP in $1998 .{ }^{4}$ Currency per capita ranges from $\$ 613$ for Finland to $\$ 3,620$ for Japan. Similarly, the currency to GDP ratio ranges from .024 for Finland to .116 for Japan. For the most part, the ordering of countries is similar for both "stock" measures of currency demand. The ordering is also consistent with the "flow" measure of currency demand summarized in Table 1.5

Several researchers have noted that it is unlikely that the average individual in these countries hold this much cash. Rogoff (1998) states that between 70 percent to 80 percent of OECD currency stock is either held by the domestic underground economy or in developing countries. In addition to household cash holdings, Rogoff argues that businesses (presumably legal ones) are very efficient in cash management and are not likely to hold much cash in OECD

\footnotetext{
${ }^{3}$ Humphrey, Pulley, and Vesala (1996) were the first, to our knowledge, to use this metric to compare cash usage across countries.

${ }^{4}$ We chose 1998 to stay sufficiently far from the introduction of the euro in 2002 and the increase in Y2K precautionary supply in 1999 for some countries.

${ }^{5}$ Germany, Switzerland, and the United States represent important exceptions, since a substantial share of the currency stock of these countries is estimated to be held abroad. We address this issue below.
} 
countries. While it is difficult to measure underground activity, some estimates suggest that it is sizable. Schneider (2006) estimates that the shadow economy in 21 OECD countries averaged 16.3 percent of GDP during the period 2002-2003. He states that the primary justification for why transactions take place in the shadow economy is tax avoidance.

For certain countries, these measures overstate domestic cash usage because significant holdings of their currencies are held outside their countries' borders. U.S. dollars being held outside of the United States have been estimated to be around 60 percent of total currency in circulation (U.S. Department of Treasury, 2003). ${ }^{6}$ Prior to the introduction of the Euro in 2002, up to forty percent of deutsche marks circulated outside of Germany (Seitz, 1995). Large portions of Swiss francs are believed to be either held outside of Switzerland or held in safe deposit banks inside the country (Boeschoten, 1992; Fischer, Köhler, and Seitz, 2004; and Rogoff, 1998). Rogoff (1998) also suggests that a non-trivial amount of Japanese currency is probably held outside of Japan but there is little hard evidence.

Several economists have attempted to quantify legal currency usage by studying consumption patterns. ${ }^{7}$ For instance, Humphrey (2004) calculates total cash purchases as the residual of personal consumption that is not captured by check, debit card, or credit card registered transactions. Humphrey eliminates $\$ 50$ and $\$ 100$ notes from his estimation to better gauge legal uses of currency. Humphrey estimates that cash share of legal consumer payments fell from .31 in 1974 to .20 in 2000 in the United States.

For Sweden, Andersson and Guibourg (2001) estimated that cash payments in registered sales (those for which value-added tax are collected) declined by 18 percent between 1991 and 1999. They suggest that almost all of the decline has been due to greater usage of payment

\footnotetext{
${ }^{6}$ Lambert and Stanton (2001) and Porter and Judson (1996) discuss foreign demand of U.S. currency.

${ }^{7}$ See Carbo Valverde, Humphrey, and Lopez del Paso (2003), Humphrey, Kaloudis, and Øwre (2004), and Snellman, Vesala, and Humprey (2001).
} 
cards. However, they are unable to explain 45 percent to 65 percent of cash holdings. They suggest that anonymity may be a critical factor in continued cash usage especially for transactions that use the 1,000 Swedish krona note. ${ }^{8}$

\section{Literature Review}

The theoretical literature on money demand is quite large. ${ }^{9}$ Many models extend the Baumol (1952)-Tobin (1956) model where interest rates, income, and the acquisition costs of cash including shoe leather costs, determine the supply of money. Payment practices and transactions costs are fundamental features of these models. ${ }^{10}$

This article best fits in the empirical literature that investigates changes in cash demand resulting from the adoption of new payment infrastructure for cash or non-cash payment alternatives. The empirical literature on cross-country payment usage continues to grow. Extensive research in the area of Dutch currency usage and the adoption of alternative payment media was done by Boeschoten (1992). He noted the difficulty in disentangling the transactional use from other uses of currency, most notably hoarding. He found that adoption of credit cards and "point-of-sale transactions" were responsible for 40 percent of the fall in currency ratio between 1965 and 1975. However, this trend reversed from 1975 to 1990 indicating an increased role for banknotes as a store of value. He estimates that 50 percent to 60 percent of the Dutch currency was hoarded in 1990.

In addition to his study of Dutch money demand, Boeschoten estimated money demand using a 15-country panel. He found significant hoarding in these countries as well. He was able to predict future currency holdings based on the adoption of payment cards but not for all the

\footnotetext{
${ }^{8}$ As of December 31, 2006, the Swedish krona/U.S. dollar rate was 6.85 .

${ }^{9}$ Duca and VanHoose (2004) reviews this literature.

${ }^{10}$ For more recent models using an inventory approach, see Alvarez, Atkeson, and Edmond (2003).
} 
countries in his sample. He also analyzed percentage of currency held by financial institutions and found that on average 13 percent of currency outstanding is held by financial institutions for the countries in his sample.

Humphrey, Pulley, and Vesala (1996) (henceforth HPV) studied the factors influencing the migration to less costly payment alternatives such as debit cards and electronic and paper giros. They looked at 14 countries for the time period from 1987 to 1993 . They used five regressions where the dependent variable was the annual transactions volume of one of the five payment instruments (check, electronic or paper giro, credit card, and debit card). Their independent variables included the prices of each payment instrument (only available for 10 of the countries), real GDP, number of POS and ATM terminals, lagged volumes of the other payment instruments, cash holdings per person, violent crime, and concentration ratio of the largest five banks.

They found the following. The influence of prices was modest because often prices for payment instruments did not vary much during their sample period and bundled across all account services. POS and ATM terminals are strongly positively related to debit card usage suggesting that similar infrastructure is used. They found that all payment instruments except for debit cards substitute for cash. The institutional variables measuring crime and banking concentration were not stable across different econometric models.

Unlike HPV, Drehmann, Goodhart, and Krueger (2002) (henceforth DGK) regress aggregate cash holdings per capita on several macro variables (real GDP per capita, nominal interest rates, and tax GDP ratio), two payment infrastructure variables (ATMs and POS terminals), and crime. They divide currency into large bills (greater than 50 British pounds) and small bills (less than 50 British pounds). Their rationale for this division is to separate illegal use of cash from transactional use. While they get significant estimates for the coefficients for the 
macro variables, they do not get significant results for the payment infrastructure variables or crime.

Another approach to isolate the impact of debit cards on cash usage is to survey individuals and their payment habits. While surveys of relatively small sample of individuals over a small period of time has its limitations, these studies may help to explain the demand for cash given payment alternatives from a microeconomic aspect that is not present in aggregate studies of money demand. For Austria, Stix (2003) finds that those individuals that make purchases frequently with debit cards on average hold 20 percent less cash in their wallets and those that frequent ATMs hold 18 percent less cash in their wallets. For France, Bounie and François (2006) find that transaction size, type of good and where the purchase is made are key factors for the consumer choice of a payment instrument. ${ }^{11}$ They also find that cash and checks, not surprisingly, are common when merchants do not accept payment cards. In addition, they are able to confirm well-established demographic factors that determine payment usage such as age, education, and gender.

\section{Data}

We employ three different data sources. For payment data, currency outstanding, population, and banking infrastructure, we use the Bank for International Settlements' Committee of Payment Settlement Systems' Statistics on Payment and Settlement Systems in Selected Countries (Red Book) and the European Central Bank's Payment and Securities Systems in the European Union (Blue Book). ${ }^{12}$ We also contacted several central banks for clarification and to fill in some of the missing data. For short-term interest rates, foreign

\footnotetext{
${ }^{11}$ For theoretical models that address the link between size of transaction and payment instrument, see Shy and Tarkka (2002) and Whitesell (1992).

${ }^{12}$ We used the Blue Book for Austrian and Finnish data.
} 
exchange rates, gross domestic product, and the ratio of self-employed to total employment, we use the International Monetary Fund's International Financial Statistics.

A key dependent variable in our regressions is the ratio of outstanding currency to GDP. Cash outstanding includes holdings by businesses, individuals and financial institutions but excludes cash held at central banks. For euro countries, we only consider the period from 1988 to 1999 , which eliminates the last two pre-Euro years in which currency stocks (particularly those of large-denomination notes) started to decline in anticipation of the regime switch. For the other countries, the sample period is from 1988 to 2003.

For certain regressions, we divide cash outstanding/GDP into three categories - large, medium, and small denominations. The Red and Blue books provide currency outstanding for each note denominations and coin type. The medium denomination note category was chosen by surveying the central banks of the respective countries to determine which denomination was prevalently distributed by ATMs. Denominations above this threshold were categorized as large denominations, while those below this threshold (including coins) were categorized as small denominations.

In some countries, only a single currency note is commonly distributed by ATMs (e.g., the $\$ 20$ note in the United States). In other countries (e.g. Germany), ATMs routinely provide a set of different denominations. In such cases, we categorize all of the ATM-distributed denominations as medium. Table 3 summarizes the data on currency denominations and ATM conventions in each of the countries in our sample. The large category includes denominations above "medium" and small includes denominations below "medium" along with coins. If the highest denomination is also the main denomination for ATM withdrawals (as is the case in Japan with the $¥ 10,000$ note), we categorize it as large. Other currency such as a US $\$ 2$ 
banknote, commemorative or limited edition coins or banknotes were excluded from the denomination data.

In several countries higher denomination coins were introduced during our sample period, replacing, in some cases, paper notes of similar value. In these cases, we kept the coin and note within the same denomination category. In addition, certain currency denominations were replaced by new denominations. In these cases, we kept both new note and the old note that it was replacing in the same category.

As mentioned in the introduction, Germany, Switzerland, and the United States have a sizable fraction of their currencies held outside their countries' borders. Since foreign holdings are much less likely to be influenced by domestic cash and debit card infrastructure, we need to adjust our cash measures. In the case of the United States, we use the Flow of Funds Accounts series on currency holdings abroad. For Germany, we utilize the time series estimates of Fisher, Kohler, and Seitz (2004). ${ }^{13}$ Data limitations prevent us from making any adjustments for Swiss currency stocks.

The following variables were taken from the Red and Blue books: number of ATMs, number of POS debit card terminals, number of debit cards, number of checks, and number of bank branches. Each of these variables was normalized to per capita terms by dividing each variable by the population of each country during that year with the exception of POS debit terminals. POS debit terminals were normalized by 10,000 individuals.

As in any cross-country study, certain variables may not be defined consistently. For example, definitions of debit cards vary somewhat across countries. Although "debit" transactions are usually associated with nearly immediate withdrawal of funds, in some countries (e.g. France) "debit" cards include those in which the funds may be withdrawn up to one month

\footnotetext{
${ }^{13}$ Since holdings of domestic currency abroad are heavily concentrated in large denomination notes (Judson and Porter, 1996), we subtract the estimated foreign holdings from large denomination notes series for both Germany and the United States.
} 
following the transaction. Because in most countries in our sample, PIN-based debit cards are much more widely used than signature-based cards and data for PIN-based transactions are more consistent, we focus on the usage of PIN-based debit cards. In most countries in our sample, all debit cards are PIN-based.

\section{Adoption of Debit Cards}

The ultimate goal of this paper is to understand the relationship between electronic cash substitutes like debit cards and demand for currency. Observed debit card transactions appear to be a good gauge of the extent to which such cards represent a viable alternative to cash. However, using transactions data directly to explain fluctuations in cash demand presents two empirical problems. The first problem is one of measurement. In several countries, reported debit card transaction data are incomplete, in the sense that they only capture a part of debit card payments. For instance, in the United States, signature debit card payments are executed over credit card networks and do not consistently appear as a part of "debit" transactions. In some cases, credit and debit card transactions are not separated, e.g. France. The second problem is econometric. A flow measure of debit card use is an endogenous variable, in the sense that it is influenced by the same factors that affect transactional cash demand. Some of these factors may be unobserved or unavailable, making coefficient estimates on debit card transactions both biased and inconsistent. One example of such an omitted factor is the cost of debit card use, which clearly influences both cash and debit use in transacting payments.

To circumvent these problems to some extent, we rely on measures of debit card infrastructure rather than usage, namely, the number of debit cards in circulation and the number

of debit card terminals. Both of these variables are measured more precisely, and are less likely to be directly affected by omitted factors influencing cash usage. For example, the consumer 
cost of a debit card transaction is less likely to be reflected in the number of debit card terminals installed by merchants. Yet, it may offer a reasonable proxy of merchant expectations on debit card use at the point of sale.

Instrumenting debit card usage by these infrastructure variables has an additional benefit in that it allows us to study the factors influencing debit card adoption. In particular, we are interested in whether consumer or merchant acceptance contributed to the takeoff of debit cards and an alternative payment instrument. As mentioned before, debit and ATM functionality usually reside on the same card. Therefore, many debit cards were held by consumers before they were able to use them to make purchases. On the other hand, merchant acceptance was contingent on the expectation that debit cards would be used if terminals were installed and the net benefits of accepting debit cards were greater than accepting alternative payment media.

Clearly, a key factor in deciding to accept debit cards is the cost of doing so. Recently, economists have applied two-sided market analysis to payment cards to study pricing of payment services. ${ }^{14}$ The literature on two-sided markets stresses that the proportion of the total price paid by each end-user group need not be symmetric to achieve optimal usage levels. In fact, many two-sided markets have asymmetric pricing between end-users such as newspapers (readers and advertisers), Adobe Acrobat (creators and readers of PDF files), and dating clubs (women may be let in at a reduced price and men pay a higher fee).

For the most part, consumers do not pay per-transaction debit card fees. ${ }^{15}$ Although there may be a bundled fee for a transaction account, once that is paid the marginal cost to use a debit card is close to zero. In most instances, merchants that accept debit cards face fixed and per-

\footnotetext{
${ }^{14}$ For more on two-sided markets, see Armstrong (2004) and Rochet and Tirole (2003).

${ }^{15}$ There are some exceptions. While not common, a few U.S. merchants impose surcharges on PIN-based debit transactions (Chakravorti and Shah, 2003). In addition, some U.S. financial institutions impose per-transaction fees for PIN-based debit card transactions.
} 
transaction fees. ${ }^{16}$ While we do not have pricing data, we can compare adoption of debit cards by consumers and merchants by looking at the number of debit cards and debit terminals, respectively.

Table 4 presents data on the number of debit terminals per 10,000 individuals along with debit cards/person in 2003. ${ }^{17}$ Countries in our sample that have high debit card usage also generally have high card adoption by consumers and high adoption of terminals by merchants. However, this relationship is far from uniform. For instance, Italy has relatively few debit cards per capita despite having a high number of debit terminals. Also noteworthy is that while Japan has three times as many debit cards in circulation as residents, the adoption of debit terminals is the lowest in our sample. Thus, both debit terminals and debit cards are required for a high number of debit card transactions.

To study the evolution of debit card usage within a country, we use a fixed effects econometric model with clustered standard errors. Specifically, our regression is:

Debit Transactions $_{\mathrm{it}}=\alpha+\beta_{1}$ Debit Cards $_{\mathrm{it}}+\beta_{2}$ Debit Terminals $_{\mathrm{it}}+\beta_{3}$ ATM $_{\mathrm{it}}+\beta_{4}$ Checks $_{\mathrm{it}}$

$$
+\beta_{5} \text { Bank Branches }_{\mathrm{it}}+\beta_{6} \text { Share of Self-Employed }_{\mathrm{it}}+\beta_{7} \text { STIR }_{\mathrm{it}}+\varepsilon_{\mathrm{it}}
$$

Using the country fixed effects specification means that we are effectively trying to explain changes in debit card acceptance in a given country by changes in debit card infrastructure and in control variables. These control variables are intended to capture competitive pressures from other payment instruments (cash and checks), as well as the costs of facilitating debit card transactions.

\footnotetext{
${ }^{16}$ Van Hove (2004b) reports that merchants in Denmark do not pay any per-transaction fees when accepting debit cards.

${ }^{17}$ Canada is an exception, as the number of debit cards there was last reported in 2000.
} 
To lessen endogeneity concerns mentioned above, we use measures of the extent of cash infrastructure to proxy for cash "competitiveness." These measures are the number of ATMs and bank branches. The relationship between debit card usage and ATM is ambiguous because greater usage of ATMs may encourage greater comfort with card payments. On the other hand, a greater number of ATMs allows easier access to cash and may lead to greater dependence on cash for payments. Similarly, more bank branches suggest lower acquisition costs of cash, thereby encouraging greater reliance on cash. For alternative paper-based payment infrastructure, we include check volumes. Many U.S. studies have suggested that debit cards substitute for checks. In countries that use checks, we would expect a negative relationship between debit card and check transactions.

The cost of facilitating debit card transactions depends, in part, on merchant size distribution. In particular, smaller merchants would be more reluctant to invest in debit card terminals because their transaction volume may not recover the fixed cost. This is especially the case if such merchants still have to accept cash and still incur cash handling costs. Thus, to capture the extent to which merchants can rely on economies of scale in debit card terminal acquisition, we look at the country- and time-specific share of small merchants. One proxy for such measure is provided by the ratio of the self-employed to total employment. In Table 5, we report these ratios for 1998. Note that Italy, Austria, and Japan are near the bottom in debit card transactions and are the top three in terms of proportion of self-employed to total employment. While fixed effect panel estimation does not allow analysis of the cross-sectional relationships, we use this variable to control for consolidation in the retail industry. A more traditional measure of cost of debit card use is their opportunity cost relative to non-interest-bearing payment instruments such as cash. To the extent that demand deposit accounts linked to debit 
cards generate a positive (albeit low) nominal rate of return, we would expect the number of debit card transactions to rise with short-term interest rates.

All variables in (1) are in logarithms with subscripts $i$ and $t$ indicating, respectively, an observation in country $i$ in year $t$. The number of debit card transactions, debit cards in circulation, ATMs, checks written, and bank branches is expressed in per capita terms, while the number of point-of-sale debit card terminals is defined in units per 10,000 residents. ${ }^{18}$ The Share of Self-Employed is based on the IMF annual employment composition data for each country, and $S T I R_{\mathrm{it}}$ is defined as the short-term interest rate in country $i$ in year $t$.

In Table 6, we report our regression results. Shading indicates coefficient estimates that are statistically significant at least at the $5 \%$ level. In regression (1) (column 1 in Table 6), the only variable proxying for debit card infrastructure is the number of debit cards, which is found to be a strong indicator of greater debit card use. In this specification, the number of ATMs also has a significant positive effect on debit card transactions, while checks detract from debit card usage. The sign on self-employed is opposite from what we expected, as is that on the shortterm interest rate.

However, these results are sensitive to a specific measure of debit card infrastructure. In regression (2) that uses the number of debit card terminals, none of the control variables (with the exception of the short-term interest rate) retains statistical significance. This result persists when both debit card terminals and cards are used in the regressions (column 3 in Table 6). Moreover, in that specification only the number of debit card terminals remains a strong predictor of debit card usage. Taken together, these results suggest that merchant adoption is driving debit card usage, and that the number of debit card terminals is indeed a strong instrument for transactional demand for debit cards.

\footnotetext{
${ }^{18}$ Check data prior to 2001 does not exist for the United States.
} 


\section{Debit Cards and Cash Substitution}

In this section, we study the impact on the cash/GDP ratio resulting from changes in payment infrastructure, merchant size distribution and the opportunity cost of holding cash. We assume that central banks provide an elastic supply of currency. Therefore, supply of cash equals demand for cash. All countries in our sample had their own currencies until 2002 when the Euro was introduced. Austria, Belgium, Finland, France, Germany, Italy, and the Netherlands are part of the euro area and have not issued their own currencies since 2002. Canada, Japan, Sweden, Switzerland, the United Kingdom, and the United States maintained their own national currencies throughout the sample period. Initially, we consider the total stock of cash outstanding for each country, but later we segment cash into large, medium and small denomination classes to isolate cash's payment function.

We plot a time series of currency to GDP ratios in figure 2. The ratio was decreasing for most countries throughout the 1970's and much of the 1980's, but flattened out for most countries since then reflecting, in part, successful stabilization of inflation. A number of geopolitical shocks that occurred since 1988 had a measurable effect on demand of certain currencies. In particular, the unification of Germany and disintegration of Yugoslavia resulted in increased demand for Deutsche marks, while the collapse of the Soviet Union greatly increased the demand for U.S. dollars (Fisher, Kohler, and Seitz, 2004; U.S. Department of Treasury, 2003). The increased demand for Japanese yen is partly attributable to an extremely low or negative inflation environment over the past 15 years.

We will econometrically test a money demand equation where the demand for money is a function of alternate payment infrastructure, cash infrastructure, proportion of small merchants, and the opportunity cost of money. We use the following econometric specification: 


$$
\begin{aligned}
\left({\text { Currency } / G D P)_{\mathrm{it}}=}_{1}\right. & \alpha+\beta_{1} \text { Debit Card Terminal }_{\mathrm{it}}+\beta_{2} \text { ATM }_{\mathrm{it}}+\beta_{3} \text { Bank Branches }_{\mathrm{it}} \\
& +\beta_{4} \text { Share of Self-Employed } \text { Sit }_{\mathrm{it}}+\beta_{5} \text { STIR }_{\mathrm{it}}+\varepsilon_{\mathrm{it}}
\end{aligned}
$$

The currency-to-GDP ratio is a convenient metric of money demand. First, it has a simple theoretical interpretation as the inverse of money velocity. Second, normalization by GDP allows us to analyze developments in multiple countries without worrying about exchange rate movements. The ratio is also likely to be stationary, although the short time dimension of our data does not allow us to take advantage of this time series property. Our definition of currency includes the outstanding stock of notes and coins. For euro countries, we only consider the period from 1988 to 1999 , which eliminates the last two pre-Euro years in which currency stocks (particularly those of large-denomination notes) started to decline in anticipation of the regime switch. For the other countries, the sample period is from 1988 to $2003 .{ }^{19}$

The vector of explanatory variables is fairly parsimonious, necessitated by a relatively small dataset and the econometric design that relies on fixed effects estimation. The standard money demand variables that capture shoe-leather and opportunity costs of cash are complemented with a measure of competing payment instruments.

As argued in the previous section, the number of debit card terminals at the point of sale is a strong instrument for the demand for debit card transactions that likely substitute for some cash transactions. $^{20}$ In Figure 3, we provide a cross-country snapshot in 1998 of the relationship between currency/GDP ratio and the number of debit terminals. In general, countries with a high number of debit card terminals tend to have lower currency/GDP ratios suggesting broadly that debit cards may be substituting for cash transactions.

\footnotetext{
${ }^{19}$ As a consequence, we have an unbalanced panel in which non-euro countries are over-represented.

${ }^{20}$ Debit cards could substitute for other non-cash transactions as well. If debit cards substituted for only non-cash transactions, the demand for cash would not be affected by debit card transactions.
} 
For cash infrastructure (or shoe-leather cost factors), we use the number of ATMs and the number of bank branches per capita. ATMs are a predominant source of cash in all the countries that we study, but the relationship between cash usage and ATMs is ambiguous. On the one hand, greater number of ATMs potentially increase the velocity of cash as consumers can access cash more easily. Hence, more ATMs would imply lower currency stocks.

However, the relationship between ATMs and cash may be changing over time depending on debit card usage at the point of sale. Initially, the introduction of ATMs increases the demand of cash of which a part is in response to filling ATMs with cash by ATM operators. In other words, a decrease in demand for cash by individuals is offset by increased demand to fill ATMs which may require idle cash especially if they are not serviced daily. The demand by ATM operators for cash may be greater than the reduction of cash holdings by consumers especially when the number of ATMs and transactions are increasing. ${ }^{21}$ Once the number of ATMs has stabilized and/or the amount of withdrawals per machine decreases resulting from greater usage of debit cards, the demand for cash by ATM operators would fall. ${ }^{22}$

We use the number of branches of financial institutions as a measure for cash access especially for non-ATM dispensed notes and coin. While payers may not mind withdrawing notes of only certain denominations, receivers of cash need to have different denominations on hand to make change. As a result, branches of financial institutions play a key role in disbursing currency of varying denominations to consumers and especially merchants. As in the case of the ATMs, a more extensive branching network may either lower day-to-day cash holdings by

\footnotetext{
${ }^{21}$ ATM owners may overstock their machines since they face reputational harm if their machines do not have cash when customers arrive. Furthermore, in some countries, ATM fees compensate ATM who have excess cash in their machines.

${ }^{22}$ Snellman and Viren (2006) argue that ATMs can be used as a strategic tool to entice consumers to use non-cash electronic payment instruments especially when there is market power in the banking sector.
} 
merchants (i.e. increase velocity) or increase overall cash holdings through filling more bank vaults or by lowering the costs of, say, converting paychecks to cash. ${ }^{23}$

The share of self-employed in total employment is a proxy for the proportion of small merchants in an economy. We expect a positive relationship between cash and the selfemployed. Smaller merchants are generally slower in adopting newer payment technologies because it takes longer to recover fixed costs and may face higher per-transaction costs. Having a more atomistic employment structure may also be associated with lower levels of tax compliance, which would also involve greater use of cash. The second column of Table 5 lists the size of shadow economies for the countries in our sample, as estimated in Schneider (2006). A simple comparison of the two columns in Table 5 suggests a positive association between the self-employed share and shadow economy size $(\rho=0.5)$. Finally, the opportunity cost of holding cash is measured by the short-term interest rate. As before, all variables are in logarithms, with debit card terminals, ATMs, and bank branches normalized by population.

\section{All Currency}

In Table 7, we report results for a number of different econometric specifications. In addition to the variables described above, we add a Y2K dummy to capture any increase in currency stock resulting from the Y2K concerns in 1999. As before, statistical significance at the $5 \%$ level or better is indicated by shading.

In the first column, we report our results using a pooled OLS regression, which treats cross- and within-country effects as interchangeable. We find that a 10 percent increase in the number of debit card terminals per capita (which is a much lower rate of growth than that realized, on average, in our sample countries) results in a 1.2 percent decrease in the currency/GDP ratio. We also find that the number of bank branches positively affects the

\footnotetext{
${ }^{23}$ However, we would expect the demand for cash by merchants would make the relationship between cash and bank branches lean in one direction.
} 
demand for currency, as does the share of self-employed. As expected, the short-term interest rate is negatively related to cash holdings.

Pooled OLS regressions applied to country panel can be problematic for two reasons. First, they do not differentiate between changes within and between countries. Second, they fail to take into account substantial serial correlation within individual countries. Thus, OLS standard errors may be severely biased, leading to incorrect statistical interpretation of the results (Petersen, 2006). Given large differences across countries exemplified, for instance, in Tables 13, we use a country fixed effects (FE) specification. As a consequence, we focus on whether within-country changes in the explanatory variables affect country-specific changes in currency demand.

While our coefficient estimates are significantly lower when employing a fixed effect econometric specification, the coefficients on debit terminals, bank branches, and short-term interest rates remain statistically significant. The coefficient on the self-employed share falls from .15 to .02 and is no longer significant. However, in the FE specification, the number of ATMs is negatively correlated with currency stock, with a 10 percent increase in ATMs resulting in a 0.4 percent decrease in the currency to GDP ratio.

The fixed effects approach addresses the second econometric problem - within-country serial correlation - only if country-specific effects are constant over time. A simple analysis of residuals from the FE regression suggests that this is not the case. Consequently, we consider two alternative methods of correcting our estimates. First, we assume that error terms $\varepsilon_{\text {it }}$ are first-order autocorrelated. Second, we compute clustered standard errors (Rogers, 1993), which allow an arbitrary temporal dependency pattern within each country (Petersen, 2006). We employ clustered standard errors both with the FE estimator and the random-effects (RE) 
estimator. The latter augments FE estimates with information on mean differences across countries.

The results of these three models, shown in columns (3)-(5) of Table 7, highlight both the importance of accounting for within-country serial correlation and the sensitivity of results to a specific choice of how to do this. In particular, while the effect of debit card terminals on currency demand is negative in all three specifications, it loses statistical significance in a simple FE model with cluster-adjusted standard errors (column 3). ${ }^{24}$ Making correlation adjustments also eliminates any identifiable effect of ATM infrastructure as well as that of the self-employed share. Only the short-term interest rates - the cornerstone of money demand models - retains statistical significance in every specification.

In sum, the results of fixed effects estimation differ substantially from those of pooled OLS regressions, particularly if necessary serial correlation adjustments are made. Again, this gives rise to two possibilities - measurement error and model misspecification.

We entertain the first possibility by restricting the sample to countries that do not have substantial foreign demand for their currency. Although we try to account for the foreign component of demand for the U.S. dollars and the Deutsche marks (see section III), these adjustments may be rather imperfect. And since all of the explanatory variables are domestic, the foreign demand component still left in the dependent variable would obscure the relationship.

Panel B of Table 7 shows the results for the sample of 10 OECD countries that exclude Germany, Switzerland, and the United States. Pooled OLS estimates from the truncated sample are quite similar to those from the full sample. Interestingly, there is now much more persistence in statistical significance of the estimates across specifications. We estimate a consistently negative effect of debit card terminals on currency demand (although it is still weaker than that

\footnotetext{
${ }^{24}$ Note that, by construction, making the clustering adjustment by itself leaves FE point estimates unchanged.
} 
estimated with pooled OLS). The share of self-employed is estimated to have a positive effect on currency demand in 3 out of 4 specifications that include country fixed effects (columns 2-4).

\section{Denomination-specific regressions}

By aggregating all currency denominations along with coins, the different roles of money may not be distinguishable. Consequently, in this subsection we categorize currency into three groups - large, medium, and small. Unlike DGK (2002), the goal of our categorization is to isolate transactional and store of value roles of currency. Our priors are that large denominations are primarily used for store of value and affected by short-term interest rates while small denominations and coins are used for transactional purposes and affected by the usage of other payment instruments such as debit cards.

Using ATM-distributed denominations as the "medium-threshold," we define large and small denomination categories as described in section III. While the ATM-dispensed banknotes form the bulk of transactional currency demand by volume, they represent a potentially noisy data source for identifying links between the growth of alternative payment instruments and cash demand. We expect smaller denomination notes and coins to be a good gauge of the changing needs of merchants and other receivers of cash to make change for purchases. Since change is given only in the case of cash transactions, changes in the stock of small notes and coins likely provide the most accurate reflection of fluctuations in transactional demand for currency. ${ }^{25}$

There are several additional benefits from partitioning the currency by denomination. Since the bulk of foreign currency demand is limited to large denominations, we expect the small- and medium-notes demand estimates to be more stable across samples (e.g. panels A and

\footnotetext{
${ }^{25}$ In the United States, some merchants, such as grocery stores, are willing to give cash back to their debit card customers. This service is analogous to cash back received for checks, a common means to acquire cash in the 1980s. Some analysts have suggested that these merchants provide cash back services to reduce their cash handling costs. However, this practice is not widespread for the countries in our sample.
} 
B in Table 7). Moreover, by isolating ATM-distributed currencies we attempt to provide a more precise estimate on what we term the ATM demand factor. As argued above, the effect of ATM on currency demand is ambiguous and existing empirical studies produce conflicting results.

Finally, if the share of self-employed affects currency demand by facilitating black market activity, we would expect to identify a relationship for the large denomination category. ${ }^{26}$ If, on the contrary, the self-employed stay away from electronic payments for cost reasons, we would expect to find an effect on demand for small denominations.

The following table summarizes our null hypotheses for denomination-specific models:

\begin{tabular}{lccc}
\hline \hline & $\begin{array}{c}\text { Smaller denominations } \\
\text { \& coins }\end{array}$ & $\begin{array}{c}\text { ATM-dispensed } \\
\text { denominations }\end{array}$ & Larger denominations \\
\hline Debit card terminals & $<\mathbf{0}$ & $?$ & $\sim \mathbf{0}$ \\
ATM access & $\sim \mathbf{0}$ & $?$ & $\sim \mathbf{0}$ \\
Bank access & $?$ & $\sim \mathbf{0}$ & $?$ \\
\hline \multirow{2}{*}{ Self-employed } & $>0$ if fixed costs & $?$ & $\sim 0$ if fixed costs \\
\hline \hline
\end{tabular}

The " 0 " notation indicates the null of no identifiable effect. A confirmation of this hypothesis for ATM and bank access variables would serve as additional evidence of the appropriateness of our currency categorization. That is, ATM density should affect only ATMdistributed categories, and bank density should have an effect only on bank-distributed categories.

Table 8 shows the results of fitting a country fixed effects model with cluster-adjusted standard errors to each denomination category. We chose FE-clustered specification since its non-parametric formulation gives us a chance to get standard errors right without making strong assumptions. It is also the only model in which debit terminals had no statistically identifiable

\footnotetext{
${ }^{26}$ Arguably, even the lemonade stand operator wishing to avoid tax payments would at some point have to convert coins and small denomination notes it collects for larger notes suitable for storing wealth or transacting.
} 
effect on total currency demand in the full sample (see panel A of Table 7). Thus, it sets a somewhat higher hurdle for the denomination-specific exercise.

Panel A of Table 8 contains full sample estimates. As expected, debit card terminals have a very strong negative effect on demand for small denominations, but not on that for medium or large denominations. Also, the ATM infrastructure is found to affect only the ATMdispensed medium category. This effect is fairly precisely identified ( $p$-value of 0.04 ) and is negative, indicating that, on net, ATM proliferation lowers the stock of ATM-dispensed notes. The bank branch infrastructure has a significant (and positive) effect only on bank-distributed denominations - i.e. those that cannot typically be obtained from ATMs. The ratio of selfemployed is influential only for small denomination demand, consistent with the hypothesis of high fixed costs of installing electronic payments terminals for small merchants.

Interestingly, we fail to find a statistically measurable effect of short-term interest rates on disaggregated currency demand. Even the large denomination notes, which in their role as store of value should reflect the opportunity costs of currency holdings, have at best a marginally significant effect ( $p$-value of 0.11 ). However, to the extent that the full sample does not account fully for foreign currency holdings, the estimated response to fluctuations in domestic short-term rates may be muted. Thus, we repeat the exercise on the truncated sample that excludes Germany, Switzerland, and the U.S.

Panel B of Table 8 presents the results for the truncated sample. This time, there is a very strong and precisely identified effect of changes in short-term interest rates on changes in largedenomination currency holdings. Importantly, all other results are very similar to those obtained for the full sample, corroborating the expectation of more stable coefficient estimates across samples. 
To check for robustness regarding the dividing lines between the denomination classes, we also run our regressions using DGK's classification. We use 50 British pounds as the cutoff between large and medium. This results in the large denomination category becoming smaller while the medium category becomes larger. The small denomination category is the same as our original one. To compare with DGK, we also report results for a category that combines the medium and small classes.

In panel A of Table 9, we report the results of our regressions. For the large denomination category, the coefficient on short-term interest rate is now significant in the full sample. Because the large classification is narrower, it is more likely that these notes are used as a store of value instead for a medium of exchange. The effect of ATMs is now being picked up in the large, and not the medium denomination category. Debit terminals are estimated to dampen the demand for both small and medium denomination notes, although the effect on medium notes is identified much less precisely. In the category where small and medium denominations are combined, only the coefficient on debit terminals is significant (and negative), suggesting that the medium notes are masking the impact of branches and the self-employed ratio.

For completeness, we show the same set of regressions without Germany, Switzerland, and the United States in panel B of Table 9. For the large denomination category, ATMs are no longer significant but are now significant for the medium category. Interestingly, the estimated ATM sign on the new "medium" specification is now negative. The results for the combined medium and small category in the truncated sample are still negatively related to the number of debit card terminals. 


\section{Conclusion}

In the 1990s, the usage of debit cards increased rapidly in all of the countries in our sample with the exception of Japan. Our empirical results suggest that the adoption of POS debit terminals by merchants was the key factor in the explosive growth in debit card usage. This suggests that both consumers and merchants generally prefer debit cards to other payment alternatives for certain types of transactions.

Despite the strong growth in the adoption of electronic payment instruments particularly debit cards, cash usage remains significant in most OECD countries suggesting that electronic alternatives have not succeeded in mimicking all the benefits of cash. For example, the anonymity feature of cash is particularly beneficial for tax evasion or illegal transactions and is a key factor for the continued demand for large denomination notes.

As we have noted, the effect of electronic payment instruments on cash usage has been studied by several researchers. However, previous studies have not been able to capture a significant effect of debit cards on cash demand using country panel estimation. A key feature of our econometric model is the ability to disentangle cash's dual roles — store of value and payment media. We are able to isolate the transactional role of cash by focusing on the small denomination class which we define as currency and coin that is lower in value than that dispensed by ATMs. The demand for these notes and coins is driven by purchases requiring merchants to make change. In contrast, electronic substitutes are able to reduce the demand for small denomination notes and coins because no change is required for these transactions. Our regression results suggest that the adoption of debit card terminals has reduced the demand for cash in small denomination notes and coin.

Our empirical results suggest that electronic alternatives to cash will indeed reduce the demand for cash of certain denominations. However, the general demand for cash will continue 
to be strong in the future because of cash's anonymity and store of value features. In addition, greater usage of OECD currencies in many emerging economies will result in a shift from domestic money demand in the country of currency issuance to money demand by residents in other countries. However, only certain OECD currencies are likely to play this role, e.g. U.S. dollar and the euro. The foreign demand for these currencies may decrease as the adoption of electronic instruments proliferates globally. 


\section{References:}

Andersson, Martin and Gabriela Guibourg (2001), "The Use of Cash in the Swedish Economy," Sveriges Riksbank Economic Review 4, 28-37.

American Bankers Association and Dove Consulting (2005), 2005/2006 Study of Consumer Payment Preferences.

Armstrong, Mark (2004), “Competition in Two-Sided Markets,” Mimeo, University College London.

Alvarez, Fernando, Andrew Atkeson, and Chris Edmond (2003), "On the Sluggish Response of Prices to Money in an Inventory-Theoretic Model of Money Demand," NBER Working Paper No. 10016, October.

Baumol, William J. (1952), “Transactions Demand for Cash: An Inventory Theoretic Approach,” Quarterly Journal of Economics 66, 545-556.

Boeschoten, Willem C. (1992), Currency Use and Payment Patterns, Financial and Monetary Policy Studies, vol. 23, Dordrecht/Boston/London: Kluwer Academic Publishers.

Borzekowski, Ron and Elizabeth K. Kiser (2006), "The Choice at the Checkout: Competition Among Payment Instruments," FEDS Working Paper, 2006-17.

Bounie, David and Abel François (2006), "Cash, Check or Bank Card?: The Effects of Transaction Characteristics on the Use of Payment Instruments," Telecom Paris Working Papers in Economics and Social Sciences ESS-06-05.

Buiter, Willem H. (2005), "New Developments in Monetary Economics: Two Ghosts, Two Eccentricities, a Fallacy, a Mirage and a Mythos," The Economic Journal 115, C1-C31.

Carbo Valverde, Santiago, David B. Humphrey, and Rafael Lopez del Paso (2003), "The Falling Share of Cash Payments in Spain," Moneda y Credito 217, 167-190

Chakravorti, Sujit (2004), "Why Has Stored Value Not Caught On?” Journal of Financial Transformation 12, 39-48.

Chakravorti, Sujit (2006), "The Evolving Payments Landscape and its Implications for Monetary Policy," in Institutional Change in the Payments System and Monetary Policy, ed Stefan W. Schmitz and Geoffrey Wood, London: Routledge, 81-92.

Chakravorti, Sujit and Victor Lubasi (2006), "Payment Instrument Choice: The Case of Prepaid Cards," Federal Reserve Bank of Chicago Economic Perspectives 30 (2), 29-43.

Chakravorti, Sujit and Timothy McHugh (2002), "Why Do We Use so Many Checks?" Federal Reserve Bank of Chicago Economic Perspectives 26 (3), 44-59. 
Chakravorti, Sujit and Alpa Shah (2003), "Underlying Incentives in Credit Card Networks," The Antitrust Bulletin, 58 (1), 53-75.

Committee on Payment and Settlement Systems (various years), Statistics on Payment and Settlement Systems in Selected Countries, Basle, Switzerland.

De Grauwe, Paul, Erik Buyst, and Laura Rinaldi (2000), "The Costs of Cash and Cards Compared: The Cases of Iceland and Belgium," mimeo.

Drehmann, Mathias, Charles Goodhart, and Malte Krueger (2002), "The Challenges Facing Currency Usage: Will the Traditional Transaction Medium be able to Resist Competition from new Technologies?," Economic Policy, April, 195-227.

Duca, John V. and David D. VanHoose (2004), "Recent Developments in Understanding the Demand for Money," Journal of Economics and Business 56, 247-272.

European Central Bank (various years), Payment and Securities and Settlement Systems in the European Union, Frankfurt, Germany.

Fischer, B., P. Kohler, and F. Seitz (2004), "The Demand for Euro Area Currencies: Past, Present, and Future," European Central Bank Working Paper Series, N. 330.

Freedman, Charles (2000), "Monetary Policy Implementation: Past Present and Future-Will the Advent of Electronic Money Lead to the Demise of Central Banking?" International Finance $3(2), 211-227$.

Friedman, Benjamin M. (1999), "The Future of Monetary Policy: The Central Bank as an Army with Only a Signal Corps?” International Finance 2 (3), 321-338.

Goodhart, Charles A. E. (2000), "Can Central Banking Survive the IT Revolution?” International Finance 3 (2), 189-209

Humphrey, David B. (2004), "Replacement of Cash by Card in U.S. Consumer Payments," Journal of Economics and Business 56, 211-225

Humphrey, David B., Aris Kaloudis, and Grete Øwre (2004), “The Future of Cash: Falling Legal Use and Implications for Government Policy," Journal of International Financial Markets, Institutions, and Money 14, 221-233.

Humphrey, David B., Lawrence B. Pulley, Jukka M. Vesala (1996), “Cash, Paper, and Electronic Payments: A Cross-Country Analysis," Journal of Money, Credit, and Banking 28 (4), part 2, 914-939.

International Monetary Fund (various years), International Financial Statistics, Washington, DC. 
Jyrkönen, Hanna (2004), "Less Cash on the Counter-Forecasting Finnish Payment Preferences," Bank of Finland Discussion Papers 27/2004.

Klee, Elizabeth (2006), “Families' Use of Payment Instruments During a Decade of Change in the U.S. Payment System," Federal Reserve Board Finance and Economics Discussion Series 2006-02.

Kroszner, Randall S. (2003), "Currency Competition in the Digital Age," ed. D. Altig and B. D. Smith, Evolution and Procedures in Central Banking, New York: Cambridge University Press, 275-299.

Lambert, Michael J. and Kristin D. Stanton (2001), "Opportunities and Challenges for the U.S. Dollar as an Increasingly Global Currency: A Federal Reserve Perspective," Federal Reserve Bulletin, September, 567-575.

Markose, Sheri M. and Yiing Jia Loke (2002), "Can Cash Hold Its Own? International Comparisons: Theory and Evidence," University of Essex, mimeo.

Petersen, Mitchell (2006), "Estimating Standard Errors in Finance Panel Data Sets: Comparing Approaches," Northwestern University, working paper.

Porter, Richard D. and Ruth A. Judson (1996), "The Location of US Currency: How Much is Abroad?," Federal Reserve Bulletin, October, 883-903.

Rochet, Jean-Charles and Jean Tirole (2003), "Platform Competition in Two-Sided Markets," Journal of European Economic Association 1 (4), 990-1029.

Rogers, W.H. (1993), "Regression Standard Errors in Clustered Samples," Stata Technical Bulletin 13, 19-23.

Rogoff, Kenneth (1998), "Blessing or Curse? Foreign and Underground Demand for Euro Notes," Economic Policy 26, 263-290.

Schneider, Friedrich (2006), "Shadow Economies and Corruption All Over the World: What Do We Really Know?," IZA Discussion Paper No. 2315, September.

Seitz, F (1995), “The Circulation of the Deutsche Mark Abroad,” Deutsche Bundesbank working paper.

Shy, Oz and Juha Tarkka (2002), "The Market for Electronic Cash Cards," Journal of Money, Credit and Banking 34, 299-314.

Snellman, Heli and Matti Viren (2006), “ATM Networks and Cash Usage,” mimeo. 
Snellman, Jussi, Jukka Vesala, and David B. Humphrey (2001), "Substitution of Noncash Payment Instruments for Cash in Europe," Journal of Financial Services Research 19: 13145.

Stix, Helmut (2003), "How Do Debit Cards Affect Cash Demand? Survey Data Evidence," Empirica, 31 (2-3), 93-115.

Tobin, James (1956), "The Interest Elasticity of Transactions Demand for Cash," Review of Economics and Statistics 38, 241-247.

U.S. Department of Treasury (2003), The Use and Counterfeiting of United States Currency Abroad, Part 2, Washington, DC, March.

Van Hove, Leo (2004a), "Cost-Based Pricing of Payment Instruments: The State of the Debate," De Economist 152 (1), 79-100.

Van Hove, Leo (2004b), "Electronic Purses in Euroland: Why do Penetration and Usage Rates Differ?" SUERF Studies 4, July.

Whitesell, William (1992), "Deposit Banks and the Market for Payment Media," Journal of Money, Credit, and Banking 24, 484-498.

Woodford, Michael (2000), "Monetary Policy in a World Without Money," International Finance 3, 229-260. 
Table 1: 2004 Per Capita Payments by Type of Instrument

\begin{tabular}{lcccccc} 
& Checks & $\begin{array}{c}\text { Debit and } \\
\text { Credit Cards }\end{array}$ & $\begin{array}{c}\text { Direct } \\
\text { Credits }\end{array}$ & $\begin{array}{c}\text { Direct } \\
\text { Debits }\end{array}$ & $\begin{array}{c}2004 \\
\text { Total }\end{array}$ & $\begin{array}{c}2001 \\
\text { Total }\end{array}$ \\
\hline \hline Austria & 1 & 21 & 109 & 75 & 206 & 213 \\
Belgium & 2 & 64 & 76 & 20 & 162 & 151 \\
Canada & 43 & 143 & 25 & 19 & 230 & 220 \\
Finland & 0 & 112 & 110 & 16 & 238 & 221 \\
France & 66 & 75 & 42 & 41 & 224 & 219 \\
Germany & 1 & 27 & 75 & 73 & 177 & 163 \\
Italy & 8 & 19 & 18 & 8 & 53 & 50 \\
Japan & 1 & 24 & 10 & NAV & 36 & 31 \\
Netherlands & 0 & 80 & 78 & 65 & 222 & 214 \\
Sweden & 0 & 109 & 51 & 16 & 177 & 146 \\
Switzerland & 0 & 49 & 79 & 7 & 135 & 130 \\
United Kingdom & 35 & 94 & 44 & 43 & 216 & 203 \\
United States & 119 & 132 & 17 & 20 & 288 & 275 \\
\hline \hline
\end{tabular}

Source: BIS CPSS Red Books and ECB Blue Books various years. 
Table 2: Cash Holdings (USD) per Capita and Currency/GDP in 1998

\begin{tabular}{lcc} 
Country & Currency/Capita & Currency/GDP \\
\hline \hline Finland & 613 & 0.024 \\
United Kingdom & 738 & 0.03 \\
Canada & 806 & 0.039 \\
France & 847 & 0.034 \\
Sweden & 1226 & 0.044 \\
Italy & 1251 & 0.06 \\
Netherlands & 1311 & 0.053 \\
Belgium & 1365 & 0.056 \\
Austria & 1677 & 0.064 \\
United States & 1850 & 0.059 \\
Germany & 1875 & 0.072 \\
Switzerland & 3408 & 0.091 \\
Japan & 3620 & 0.116 \\
\hline \hline
\end{tabular}

Source: BIS CPSS Red Books and ECB Blue Books various years. 
Table 3: Highest Denomination and ATM notes in 13 OECD countries

\begin{tabular}{|c|c|c|c|c|c|}
\hline \multirow[b]{2}{*}{ National Currency } & \multicolumn{2}{|c|}{ Highest Denomination } & \multicolumn{2}{|c|}{ Most common ATM note } & \multirow{2}{*}{$\begin{array}{c}\text { October 19, } 2000 \\
\text { Exchange rate } \\
(\mathrm{NCU} / \$) \\
\end{array}$} \\
\hline & $\mathrm{NCU}$ & US \$ & $\mathrm{NCU}$ & US \$ & \\
\hline Austria Schillings & 5,000 & $\$ 305$ & $100-1,000$ & $\$ 6-\$ 61$ & 16.40 \\
\hline Belgium Francs & 10,000 & $\$ 208$ & 1000 & $\$ 21$ & 48.08 \\
\hline Canada Dollars & 1,000 & $\$ 658$ & 20 & $\$ 13$ & 1.52 \\
\hline Finland Markkaa & 1,000 & $\$ 141$ & 100 & $\$ 14$ & 7.09 \\
\hline France Francs & 500 & $\$ 64$ & 100 & $\$ 13$ & 7.82 \\
\hline Germany Deutsche Marks & 1,000 & $\$ 429$ & $10-100$ & $\$ 4-\$ 43$ & 2.33 \\
\hline Italy Lire & 500,000 & $\$ 217$ & $10 \mathrm{~K}-50 \mathrm{~K}$ & $\$ 4-\$ 22$ & 2307.65 \\
\hline Japan Yen & 10,000 & $\$ 93$ & 10000 & $\$ 93$ & 107.73 \\
\hline Netherlands Guilders & 1,000 & $\$ 381$ & 100 & $\$ 38$ & 2.63 \\
\hline Sweden Kronor & 1,000 & $\$ 99$ & $100-500$ & $\$ 10-\$ 49$ & 10.12 \\
\hline Switzerland Francs & 1,000 & $\$ 559$ & $20-200$ & $\$ 11-\$ 112$ & 1.79 \\
\hline United Kingdom Pounds & 50 & $\$ 72$ & $10-20$ & $\$ 14-\$ 29$ & 0.69 \\
\hline United States Dollars & 100 & $\$ 100$ & 20 & $\$ 20$ & 1.00 \\
\hline
\end{tabular}

Source: CPSS Red and ECB Blue Books and correspondence with central banks 
Table 4: Debit Terminals/10,000 Residents and Debit Cards per Capita in 2003*

\begin{tabular}{lcc} 
Country & Debit Terminals/10000 & Debit Cards per Capita \\
\hline \hline Japan & 1.57 & 3.06 \\
Germany & 6.01 & 1.10 \\
Austria & 9.03 & 1.02 \\
Belgium & 10.96 & 1.33 \\
Switzerland & 11.16 & 0.83 \\
Netherlands & 11.53 & 1.34 \\
Sweden & 12.17 & 0.63 \\
United States & 13.23 & 0.89 \\
Canada & 14.24 & 1.17 \\
United Kingdom & 14.54 & 1.06 \\
Italy & 16.14 & 0.49 \\
France & 16.63 & 0.74 \\
Finland & 17.66 & 0.79 \\
\hline \hline
\end{tabular}

*For Canada, 2000 figures are taken because more recent figures are not available

Source: CPSS Red and ECB Blue Books 


\section{Table 5: Self-employed to Total Employment Ratio}

\begin{tabular}{lcc} 
Country & $\begin{array}{c}\text { Self-employed ratio } \\
(1998)\end{array}$ & $\begin{array}{c}\text { Shadow Economy as \% of official GDP } \\
(1999)\end{array}$ \\
\hline \hline France & 7.70 & 15.2 \\
United States & 7.94 & 8.7 \\
Sweden & 8.33 & 19.2 \\
Germany & 10.19 & 16 \\
Finland & 12.18 & 18.1 \\
United Kingdom & 12.88 & 12.7 \\
Switzerland & 13.61 & 8.6 \\
Netherlands & 14.82 & 13.1 \\
Canada & 17.26 & 16 \\
Belgium & 17.40 & 22.2 \\
Japan & 17.60 & 11.2 \\
Austria & 20.76 & 9.8 \\
Italy & 34.47 & 27.1 \\
\hline \hline
\end{tabular}

Source: IMF and shadow economy estimates are from Schneider (2006) 
Table 6: Debit Card Adoption

\begin{tabular}{lccc}
\hline \hline Dependent variable: $\log ($ debit card volume/pop) & 1 & 2 & 3 \\
\hline $\log$ (Debit Card Number/pop) & 0.67 & & 0.12 \\
$\log ($ Debit Card Terminals/pop) & 4.81 & & -0.53 \\
& & 0.99 & 0.91 \\
$\log ($ ATM/pop) & & 7.25 & 5.13 \\
& 1.32 & 0.25 & 0.25 \\
$\log ($ Checkvol/pop) & 3.19 & 1.67 & 1.33 \\
& -0.51 & 0 & -0.03 \\
$\log ($ Bank branches/pop) & $(-3.72)$ & 0.02 & $-0.23)$ \\
& 1.78 & 0.17 & 0.25 \\
$\log$ (Ratio of self-employed) & 1.64 & $(0 . .29)$ & 0.45 \\
& 38.58 & 9.56 & 14.27 \\
$\log$ (Short-term interest rate) & 2.25 & -1.03 & 1.29 \\
& -13.9 & -4.78 & -4.97 \\
$\operatorname{constant}$ & $(-2.81)$ & $(-2.04)$ & $(-1.88)$ \\
$\mathrm{N}$ & & & -7.06 \\
Goodness-of-fit measure & -12.51 & -5.94 & 182 \\
\hline \hline
\end{tabular}


Table 7: Various Econometric Models of Simple Currency Demand

Panel A: 13 OECD countries, pre-Euro if applicable

Corrections for country-level serial correlation

Dependent variable: $\log$

Fixed Effects FE with cluster- FE with AR(1) RE with cluster-

(currency stock / GDP ratio) Pooled OLS adjusted SE

$\log$ (Debit terminals/pop)

$-0.12$

(FE)

errors adjusted SE

$\log (\mathrm{ATMs} / \mathrm{pop})$

$(-10.3)$

$-0.02$

$-0.02$

$-0.05 \quad-0.03$

$-0.05$

$(-2.19)$

$(-1.43)$

$(-3.47)$

$(-2.32)$

$\log ($ Bank branches/pop)

$(-1.3)$

$-0.04$

$-0.04$

0.06

$-0.01$

$(-2.13)$

$(-1.34)$

(1.69)

$(-0.29)$

0.46

0.30

0.30

0.11

0.36

(9.52)

(5.78)

(4.17)

(1.58)

(5.68)

$\log$ (Ratio of self-employed)

0.02

0.02

0.14

0.14

(3.77)

$(0.32)$

$(0.15)$

(1.02)

(1.26)

$\log ($ Short-term interest rate)

$-0.30$

$-0.07$

$-0.07$

$-0.03$

$-0.09$

$(-10.5)$

$(-4.27)$

$(-3.18)$

$(-2.09)$

$(-4.05)$

Y2K dummy

0.01

0.04

0.04

0.09

0.04

(0.19)

(1.3)

(1.8)

(7.23)

(1.86)

constant

2.04

1.82

1.82

1.46

1.61

$\mathrm{N}$

169

169

169

156

169

Goodness-of-fit measure

adj. $\mathrm{R}^{2}$

within $\mathrm{R}^{2}$

within $\mathrm{R}^{2}$

within $\mathrm{R}^{2}$

overall $\mathrm{R}^{2}$

0.67

0.31

0.31

0.36 0.57

Panel B: 10 OECD countries, pre-Euro if applicable; exclude Germany, Switzerland, and US as countries with a large share of currency abroad or out of circulation.

Corrections for country-level serial correlation

Dependent variable: $\log$

Fixed Effects FE with cluster- FE with AR(1) RE with cluster-

(currency stock / GDP ratio)

(FE)

$\log$ (Debit terminals/pop)

$-0.12$

$-0.02$ adjusted SE errors

$-0.07$ adjusted SE

$\log$ (ATMs/pop)

$(-8.45)$

$(-2.68)$

$-0.02$

$(-2.04)$

$(-4.12)$

$-0.04$

$-0.13$

$-0.03$

$-0.03$

0.04

$(-2.79)$

$(-3.07)$

$(-1.78)$

$(-1.09)$

(1.11)

$-0.01$

$\log$ (Bank branches/pop)

0.26

0.35

0.35

0.23

$(-0.24)$

(3.56)

(7.4)

(4.51)

(2.63)

0.35

$\log$ (Ratio of self-employed)

0.22

0.22

0.33

(4.42)

(4.89)

(2.13)

(1.00)

(2.08)

0.33

$-0.31$

$-0.09$

$-0.09$

$-0.03$

(2.31)

$(-9.67)$

(-4.89)

(-4.36)

$(-2.05)$

$-0.12$

0.00

0.04

0.04

0.07

(-4.64)

$(-0.02)$

(1.2)

(1.71)

(5.47)

0.03

1.61

1.33

1.33

1.01

(1.63)

constant

128

128

128

118

128

\begin{tabular}{lccccc}
$\mathrm{N}$ & 128 & 128 & 128 & 118 & 128 \\
& adj. $\mathrm{R}^{2}$ & within $\mathrm{R}^{2}$ & within $\mathrm{R}^{2}$ & within $\mathrm{R}^{2}$ & overall $\mathrm{R}^{2}$ \\
Goodness-of-fit measure & 0.71 & 0.43 & 0.43 & 0.39 & 0.52 \\
\hline \hline
\end{tabular}


Table 8: Denomination-specific currency demand: FE model with cluster-adjusted SEs

$\begin{array}{ll} & \text { Large: greater than ATM-dispensed } \\ \text { Original classification } & \text { Medium: } A T M \text {-dispensed notes } \\ & \text { Low: less than ATM-dispensed notes +coin }\end{array}$

Panel A: 13 OECD countries, pre-Euro if applicable note: same as alt.

\begin{tabular}{lccc}
\hline \hline & \multicolumn{3}{c}{ logarithm of } \\
\cline { 2 - 4 } Dependent variable: & Large/GDP & Medium/GDP & Small/GDP \\
\hline $\log ($ Debit terminals/pop) & 0.00 & 0.03 & -0.04 \\
& $(-0.16)$ & $(0.88)$ & $(-3.69)$ \\
$\log ($ ATMs/pop) & -0.03 & -0.24 & 0.00 \\
& $(-0.29)$ & $(-2.25)$ & $(0)$ \\
$\log ($ Bank branches/pop) & 0.42 & 0.21 & 0.27 \\
& $(2.53)$ & $(1.04)$ & $(2.91)$ \\
$\log ($ Ratio of self-employed) & -0.34 & 0.29 & 0.32 \\
& $(-1.12)$ & $(1.3)$ & $(3.16)$ \\
$\log$ (Short-term interest rate) & -0.06 & -0.04 & -0.02 \\
& $(-1.65)$ & $(-1.57)$ & $(-1.46)$ \\
Y2K dummy & 0.02 & 0.02 & 0.00 \\
& $(0.34)$ & $(0.73)$ & $(-0.12)$ \\
$\operatorname{constant}$ & -2.57 & -4.95 & -5.81 \\
& & & 169 \\
$\mathrm{~N}$ & 169 & 169 & within $\mathrm{R}^{2}$ \\
Goodness-of-fit measure & within $\mathrm{R}^{2}$ & within $\mathrm{R}^{2}$ & 0.66 \\
\hline \hline
\end{tabular}

Panel B: 10 OECD countries, pre-Euro if applicable; exclude Germany, Switzerland, and US as countries with a large share of currency abroad or out of circulation.

\begin{tabular}{lccc}
\hline \hline & \multicolumn{3}{c}{ logarithm of } \\
\cline { 2 - 4 } Dependent variable: & Large/GDP & Medium/GDP & Small/GDP \\
\hline $\log$ (Debit terminals/pop) & -0.03 & 0.03 & -0.04 \\
& $(-1.13)$ & $(1.15)$ & $(-3.21)$ \\
$\log$ (ATMs/pop) & 0.05 & -0.27 & 0.00 \\
& $(0.78)$ & $-2.75)$ & $(0.09)$ \\
$\log$ (Bank branches/pop) & 0.47 & 0.26 & 0.30 \\
& $(2.56)$ & $(1.29)$ & $(2.97)$ \\
$\log$ (Ratio of self-employed) & 0.22 & 0.24 & 0.40 \\
& $(0.88)$ & $(0.54)$ & $(2.69)$ \\
$\log$ (Short-term interest rate) & -0.13 & -0.03 & -0.03 \\
& $(-5.24)$ & $(-0.76)$ & $(-1.59)$ \\
Y2K dummy & 0.05 & 0.00 & -0.01 \\
& $(1.63)$ & $(-0.01)$ & $(-0.48)$ \\
constant & -3.81 & -5.00 & -6.07 \\
N & 128 & & 128 \\
& adj. $\mathrm{R}^{2}$ & within $\mathrm{R}^{2}$ & within $\mathrm{R}^{2}$ \\
Goodness-of-fit measure & 0.26 & 0.46 & 0.64 \\
\hline \hline
\end{tabular}


Table 9: Denomination-specific currency demand: FE model with cluster-adjusted SEs

Large: greater than $50 \mathrm{GBP}$

Alternative classification Medium: ATM-dispensed notes if less than 50GBP

Low: less than ATM-dispensed notes+coin

Panel A: 13 OECD countries, pre-Euro if applicable

\begin{tabular}{|c|c|c|c|c|}
\hline \multirow[b]{2}{*}{ Dependent variable: } & \multicolumn{3}{|c|}{ logarithm of } & \multirow[b]{2}{*}{ (Medium+Small)/GDF } \\
\hline & Large/GDP & Medium/GDP & Small/GDP & \\
\hline log(Debit terminals/pop) & $\begin{array}{c}0.06 \\
(1.44)\end{array}$ & $\begin{array}{l}-0.06 \\
(-2.01)\end{array}$ & $\begin{array}{l}-0.04 \\
(-3.69)\end{array}$ & $\begin{array}{l}-0.06 \\
(-2.3)\end{array}$ \\
\hline $\log (\mathrm{ATMs} / \mathrm{pop})$ & $\begin{array}{l}-0.26 \\
(-1.99)\end{array}$ & $\begin{array}{l}0.12 \\
(1.4)\end{array}$ & $\begin{array}{c}0.00 \\
(0)\end{array}$ & $\begin{array}{l}0.09 \\
(1.34)\end{array}$ \\
\hline $\log ($ Bank branches/pop) & $\begin{array}{l}0.56 \\
(2.31)\end{array}$ & $\begin{array}{l}-0.18 \\
(-0.95)\end{array}$ & $\begin{array}{l}0.27 \\
(2.91)\end{array}$ & $\begin{array}{l}-0.10 \\
(-0.64)\end{array}$ \\
\hline $\log$ (Ratio of self-employed) & $\begin{array}{l}-0.19 \\
(-0.53)\end{array}$ & $\begin{array}{l}-0.04 \\
(-0.19)\end{array}$ & $\begin{array}{c}0.32 \\
(3.16)\end{array}$ & $\begin{array}{l}0.04 \\
(0.21)\end{array}$ \\
\hline $\log ($ Short-term interest rate) & $\begin{array}{l}-0.09 \\
(-2.2)\end{array}$ & $\begin{array}{c}0.02 \\
(0.62)\end{array}$ & $\begin{array}{l}-0.02 \\
(-1.46)\end{array}$ & $\begin{array}{c}0.02 \\
(0.77)\end{array}$ \\
\hline Y2K dummy & $\begin{array}{l}0.04 \\
(0.65)\end{array}$ & $\begin{array}{l}0.04 \\
(1.73)\end{array}$ & $\begin{array}{c}0.00 \\
(-0.12)\end{array}$ & $\begin{array}{l}0.03 \\
(1.62)\end{array}$ \\
\hline constant & -3.42 & -3.78 & -5.81 & -3.66 \\
\hline $\mathrm{N}$ & $\begin{array}{c}169 \\
\text { within } \mathrm{R}^{2}\end{array}$ & $\begin{array}{c}169 \\
\text { within } \mathrm{R}^{2}\end{array}$ & $\begin{array}{c}169 \\
\text { within } \mathrm{R}^{2}\end{array}$ & $\begin{array}{c}169 \\
\text { within } \mathrm{R}^{2}\end{array}$ \\
\hline Goodness-of-fit measure & 0.11 & 0.21 & 0.66 & 0.26 \\
\hline
\end{tabular}

Panel B: 10 OECD countries, pre-Euro if applicable; exclude Germany, Switzerland, and US as countries with a large share of currency abroad or out of circulation.

\begin{tabular}{|c|c|c|c|c|}
\hline \multirow[b]{2}{*}{ Dependent variable: } & \multicolumn{3}{|c|}{ logarithm of } & \multirow[b]{2}{*}{$($ Medium+Small $) / G D P$} \\
\hline & Large/GDP & Medium/GDP & Small/GDP & \\
\hline $\log ($ Debit terminals/pop) & $\begin{array}{c}0.04 \\
(0.93)\end{array}$ & $\begin{array}{l}-0.07 \\
(-2.58)\end{array}$ & $\begin{array}{l}-0.04 \\
(-3.21)\end{array}$ & $\begin{array}{l}-0.06 \\
(-2.89)\end{array}$ \\
\hline $\log (\mathrm{ATMs} / \mathrm{pop})$ & $\begin{array}{l}-0.22 \\
(-1.86)\end{array}$ & $\begin{array}{l}0.15 \\
(2.18)\end{array}$ & $\begin{array}{l}0.00 \\
(0.09)\end{array}$ & $\begin{array}{l}0.12 \\
(2.05)\end{array}$ \\
\hline $\log ($ Bank branches/pop $)$ & $\begin{array}{l}0.60 \\
(2.27)\end{array}$ & $\begin{array}{l}-0.17 \\
(-0.91)\end{array}$ & $\begin{array}{l}0.30 \\
(2.97)\end{array}$ & $\begin{array}{l}-0.10 \\
(-0.59)\end{array}$ \\
\hline $\log$ (Ratio of self-employed) & $\begin{array}{l}0.26 \\
(0.71)\end{array}$ & $\begin{array}{l}0.36 \\
(1.58)\end{array}$ & $\begin{array}{l}0.40 \\
(2.69)\end{array}$ & $\begin{array}{l}0.38 \\
(2.07)\end{array}$ \\
\hline $\log ($ Short-term interest rate $)$ & $\begin{array}{l}-0.13 \\
(-4.05)\end{array}$ & $\begin{array}{l}-0.03 \\
(-1.13)\end{array}$ & $\begin{array}{l}-0.03 \\
(-1.59)\end{array}$ & $\begin{array}{l}-0.02 \\
(-0.97)\end{array}$ \\
\hline Y2K dummy & $\begin{array}{l}0.10 \\
(1.62)\end{array}$ & $\begin{array}{l}0.01 \\
(0.3)\end{array}$ & $\begin{array}{l}-0.01 \\
(-0.48)\end{array}$ & $\begin{array}{l}0.00 \\
(0.24)\end{array}$ \\
\hline constant & -4.53 & -4.82 & -6.07 & -4.53 \\
\hline $\mathrm{N}$ & $\begin{array}{c}128 \\
\text { within } \mathrm{R}^{2}\end{array}$ & $\begin{array}{c}128 \\
\text { within } \mathrm{R}^{2}\end{array}$ & $\begin{array}{c}128 \\
\text { within } \mathrm{R}^{2}\end{array}$ & $\begin{array}{c}128 \\
\text { within } \mathrm{R}^{2}\end{array}$ \\
\hline Goodness-of-fit measure & 0.27 & 0.26 & 0.64 & 0.28 \\
\hline
\end{tabular}




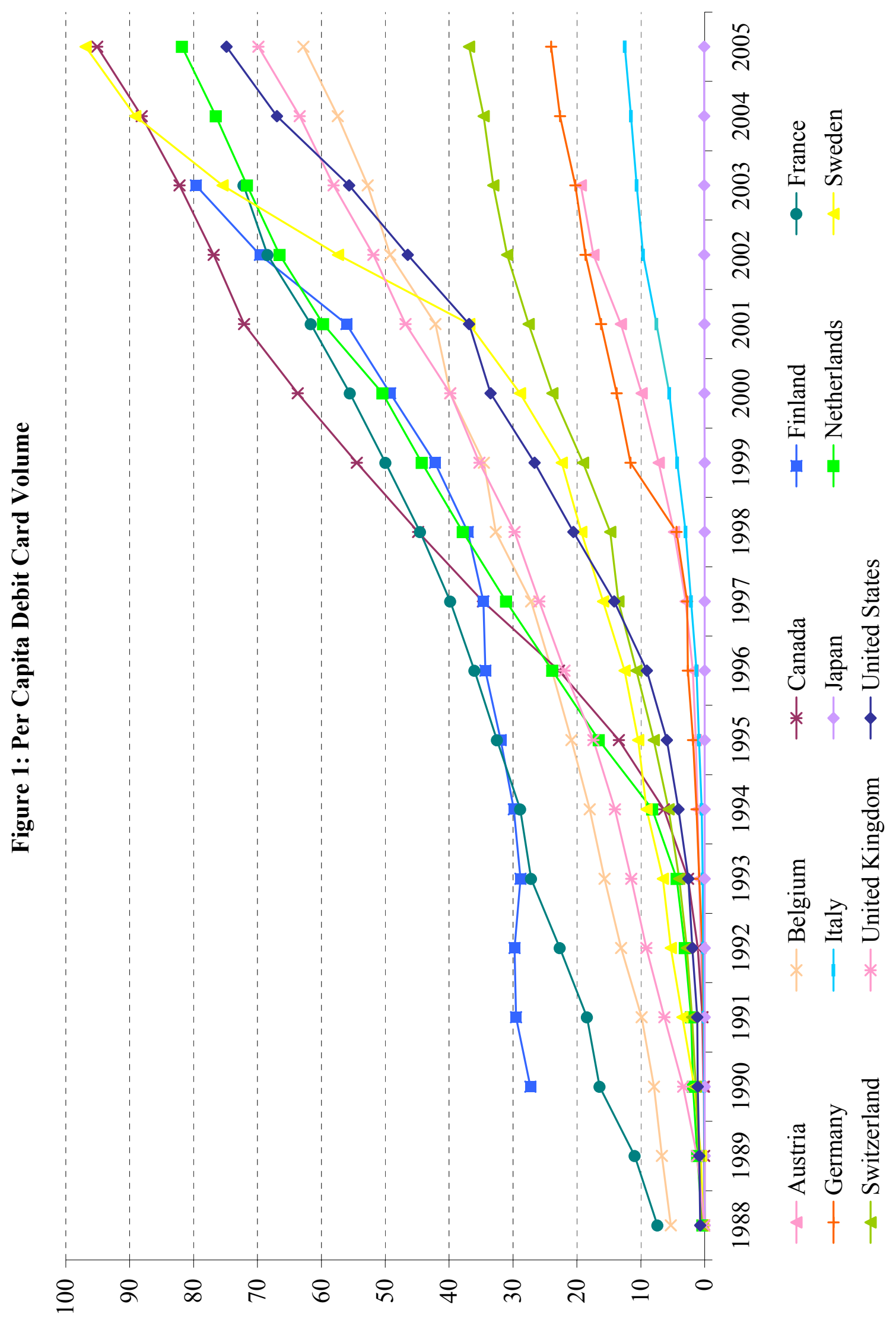




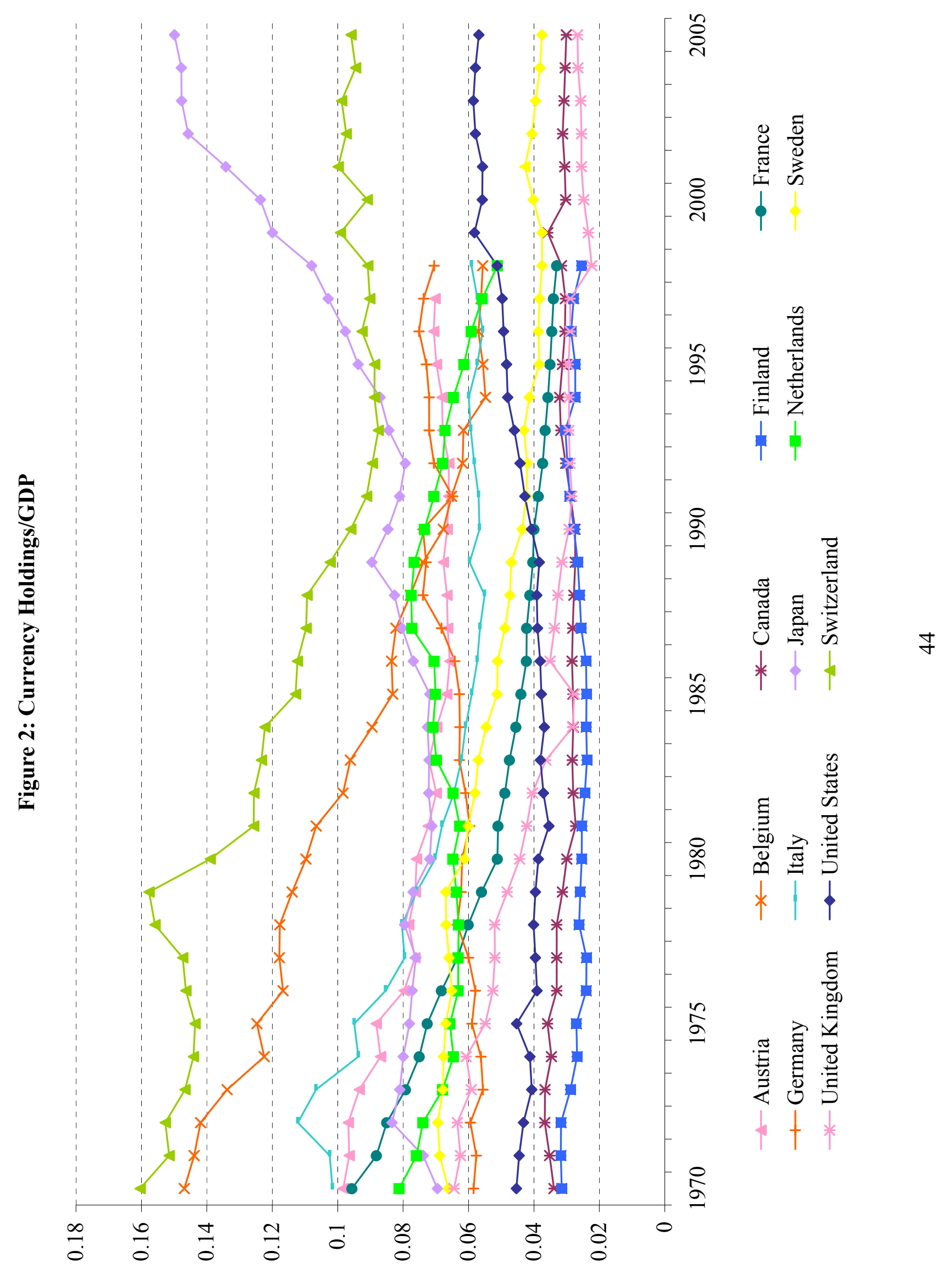




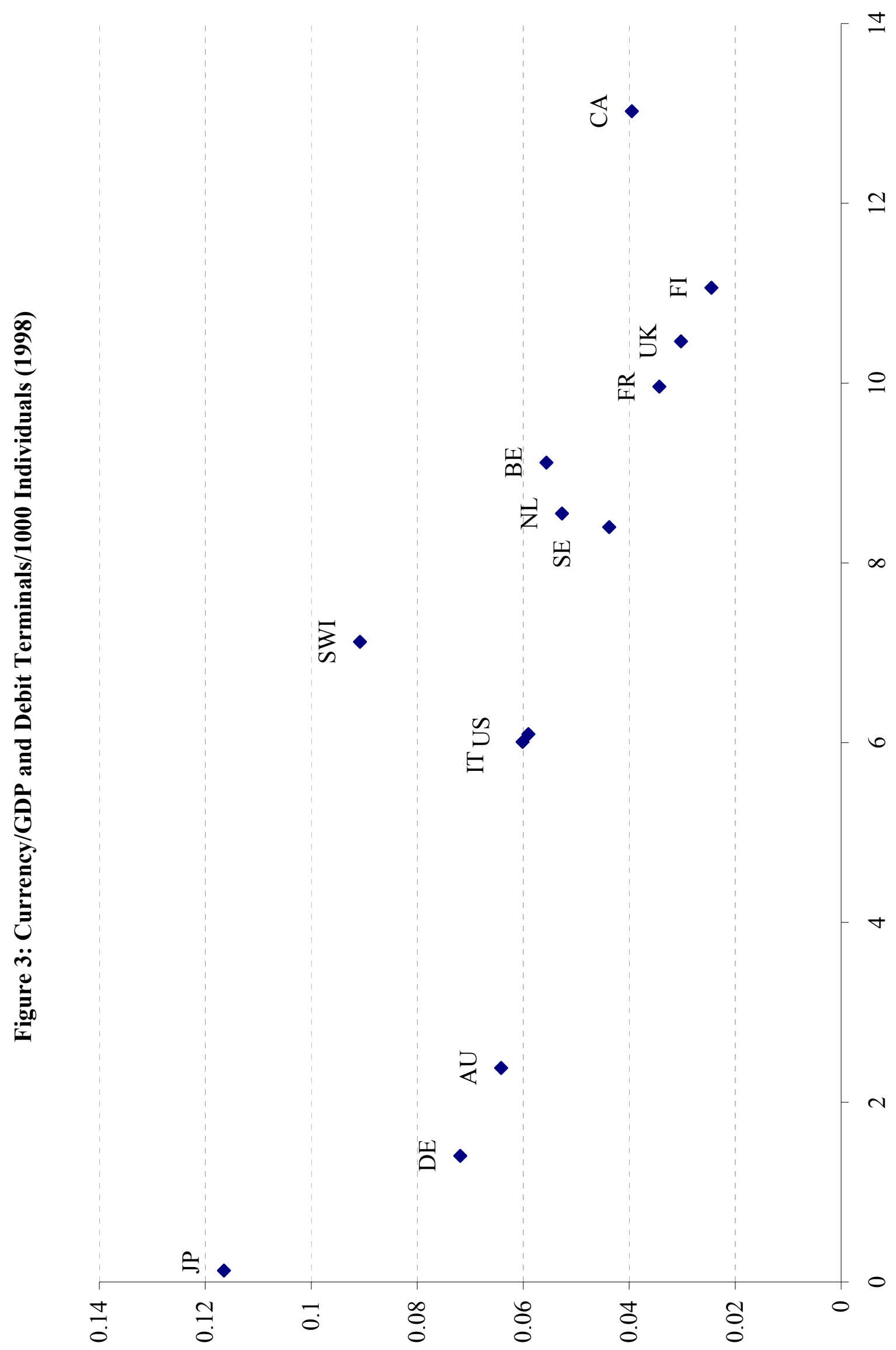




\section{Working Paper Series}

A series of research studies on regional economic issues relating to the Seventh Federal Reserve District, and on financial and economic topics.

Standing Facilities and Interbank Borrowing: Evidence from the Federal Reserve's

WP-04-01

New Discount Window

Craig Furfine

Netting, Financial Contracts, and Banks: The Economic Implications

WP-04-02

William J. Bergman, Robert R. Bliss, Christian A. Johnson and George G. Kaufman

Real Effects of Bank Competition

WP-04-03

Nicola Cetorelli

Finance as a Barrier To Entry: Bank Competition and Industry Structure in

WP-04-04

Local U.S. Markets?

Nicola Cetorelli and Philip E. Strahan

The Dynamics of Work and Debt

WP-04-05

Jeffrey R. Campbell and Zvi Hercowitz

Fiscal Policy in the Aftermath of 9/11

WP-04-06

Jonas Fisher and Martin Eichenbaum

Merger Momentum and Investor Sentiment: The Stock Market Reaction

To Merger Announcements

WP-04-07

Richard J. Rosen

Earnings Inequality and the Business Cycle

WP-04-08

Gadi Barlevy and Daniel Tsiddon

Platform Competition in Two-Sided Markets: The Case of Payment Networks

WP-04-09

Sujit Chakravorti and Roberto Roson

Nominal Debt as a Burden on Monetary Policy

WP-04-10

Javier Díaz-Giménez, Giorgia Giovannetti, Ramon Marimon, and Pedro Teles

On the Timing of Innovation in Stochastic Schumpeterian Growth Models

WP-04-11

Gadi Barlevy

Policy Externalities: How US Antidumping Affects Japanese Exports to the EU

WP-04-12

Chad P. Bown and Meredith A. Crowley

Sibling Similarities, Differences and Economic Inequality

WP-04-13

Bhashkar Mazumder

Determinants of Business Cycle Comovement: A Robust Analysis

WP-04-14

Marianne Baxter and Michael A. Kouparitsas

The Occupational Assimilation of Hispanics in the U.S.: Evidence from Panel Data

WP-04-15

Maude Toussaint-Comeau 


\section{Working Paper Series (continued)}

Reading, Writing, and Raisinets ${ }^{1}$ : Are School Finances Contributing to Children's Obesity?

of Commercial Bank M\&As

Gayle DeLong and Robert DeYoung

Prospects for Immigrant-Native Wealth Assimilation:

WP-04-18

Evidence from Financial Market Participation

Una Okonkwo Osili and Anna Paulson

Individuals and Institutions: Evidence from International Migrants in the U.S.

WP-04-19

Una Okonkwo Osili and Anna Paulson

Are Technology Improvements Contractionary?

WP-04-20

Susanto Basu, John Fernald and Miles Kimball

The Minimum Wage, Restaurant Prices and Labor Market Structure

WP-04-21

Daniel Aaronson, Eric French and James MacDonald

Betcha can’t acquire just one: merger programs and compensation

WP-04-22

Richard J. Rosen

Not Working: Demographic Changes, Policy Changes,

WP-04-23

and the Distribution of Weeks (Not) Worked

Lisa Barrow and Kristin F. Butcher

The Role of Collateralized Household Debt in Macroeconomic Stabilization

WP-04-24

Jeffrey R. Campbell and Zvi Hercowitz

Advertising and Pricing at Multiple-Output Firms: Evidence from U.S. Thrift Institutions Robert DeYoung and Evren Örs

WP-04-25

Monetary Policy with State Contingent Interest Rates

WP-04-26

Bernardino Adão, Isabel Correia and Pedro Teles

Comparing location decisions of domestic and foreign auto supplier plants

WP-04-27

Thomas Klier, Paul Ma and Daniel P. McMillen

China's export growth and US trade policy

WP-04-28

Chad P. Bown and Meredith A. Crowley

Where do manufacturing firms locate their Headquarters?

WP-04-29

J. Vernon Henderson and Yukako Ono

Monetary Policy with Single Instrument Feedback Rules

WP-04-30

Bernardino Adão, Isabel Correia and Pedro Teles 


\section{Working Paper Series (continued)}

Firm-Specific Capital, Nominal Rigidities and the Business Cycle

WP-05-01

David Altig, Lawrence J. Christiano, Martin Eichenbaum and Jesper Linde

WP-05-02

Do Returns to Schooling Differ by Race and Ethnicity?

Lisa Barrow and Cecilia Elena Rouse

Derivatives and Systemic Risk: Netting, Collateral, and Closeout

WP-05-03

Robert R. Bliss and George G. Kaufman

Risk Overhang and Loan Portfolio Decisions

WP-05-04

Robert DeYoung, Anne Gron and Andrew Winton

Characterizations in a random record model with a non-identically distributed initial record

WP-05-05

Gadi Barlevy and H. N. Nagaraja

Price discovery in a market under stress: the U.S. Treasury market in fall 1998

Craig H. Furfine and Eli M. Remolona

WP-05-06

Politics and Efficiency of Separating Capital and Ordinary Government Budgets

Marco Bassetto with Thomas J. Sargent

WP-05-07

Rigid Prices: Evidence from U.S. Scanner Data

WP-05-08

Jeffrey R. Campbell and Benjamin Eden

Entrepreneurship, Frictions, and Wealth

Marco Cagetti and Mariacristina De Nardi

WP-05-09

Wealth inequality: data and models

WP-05-10

Marco Cagetti and Mariacristina De Nardi

What Determines Bilateral Trade Flows?

WP-05-11

Marianne Baxter and Michael A. Kouparitsas

Intergenerational Economic Mobility in the U.S., 1940 to 2000

WP-05-12

Daniel Aaronson and Bhashkar Mazumder

Differential Mortality, Uncertain Medical Expenses, and the Saving of Elderly Singles

Mariacristina De Nardi, Eric French, and John Bailey Jones

WP-05-13

Fixed Term Employment Contracts in an Equilibrium Search Model

WP-05-14

Fernando Alvarez and Marcelo Veracierto

Causality, Causality, Causality: The View of Education Inputs and Outputs from Economics

WP-05-15

Lisa Barrow and Cecilia Elena Rouse 


\section{Working Paper Series (continued)}

Competition in Large Markets

WP-05-16

Jeffrey R. Campbell

Why Do Firms Go Public? Evidence from the Banking Industry

WP-05-17

Richard J. Rosen, Scott B. Smart and Chad J. Zutter

Clustering of Auto Supplier Plants in the U.S.: GMM Spatial Logit for Large Samples

Thomas Klier and Daniel P. McMillen

WP-05-18

Why are Immigrants' Incarceration Rates So Low?

Evidence on Selective Immigration, Deterrence, and Deportation

WP-05-19

Kristin F. Butcher and Anne Morrison Piehl

Constructing the Chicago Fed Income Based Economic Index - Consumer Price Index:

Inflation Experiences by Demographic Group: 1983-2005

WP-05-20

Leslie McGranahan and Anna Paulson

Universal Access, Cost Recovery, and Payment Services

WP-05-21

Sujit Chakravorti, Jeffery W. Gunther, and Robert R. Moore

Supplier Switching and Outsourcing

WP-05-22

Yukako Ono and Victor Stango

Do Enclaves Matter in Immigrants’ Self-Employment Decision?

WP-05-23

Maude Toussaint-Comeau

The Changing Pattern of Wage Growth for Low Skilled Workers

WP-05-24

Eric French, Bhashkar Mazumder and Christopher Taber

U.S. Corporate and Bank Insolvency Regimes: An Economic Comparison and Evaluation Robert R. Bliss and George G. Kaufman

WP-06-01

Redistribution, Taxes, and the Median Voter

WP-06-02

Marco Bassetto and Jess Benhabib

Identification of Search Models with Initial Condition Problems

WP-06-03

Gadi Barlevy and H. N. Nagaraja

Tax Riots

WP-06-04

Marco Bassetto and Christopher Phelan

The Tradeoff between Mortgage Prepayments and Tax-Deferred Retirement Savings

WP-06-05

Gene Amromin, Jennifer Huang, and Clemens Sialm

Why are safeguards needed in a trade agreement?

WP-06-06

Meredith A. Crowley 


\section{Working Paper Series (continued)}

Taxation, Entrepreneurship, and Wealth

WP-06-07

Marco Cagetti and Mariacristina De Nardi

A New Social Compact: How University Engagement Can Fuel Innovation

WP-06-08

Laura Melle, Larry Isaak, and Richard Mattoon

Mergers and Risk

WP-06-09

Craig H. Furfine and Richard J. Rosen

Two Flaws in Business Cycle Accounting

WP-06-10

Lawrence J. Christiano and Joshua M. Davis

Do Consumers Choose the Right Credit Contracts?

Sumit Agarwal, Souphala Chomsisengphet, Chunlin Liu, and Nicholas S. Souleles

WP-06-11

Chronicles of a Deflation Unforetold

WP-06-12

François R. Velde

Female Offenders Use of Social Welfare Programs Before and After Jail and Prison:

Does Prison Cause Welfare Dependency?

WP-06-13

Kristin F. Butcher and Robert J. LaLonde

Eat or Be Eaten: A Theory of Mergers and Firm Size

WP-06-14

Gary Gorton, Matthias Kahl, and Richard Rosen

Do Bonds Span Volatility Risk in the U.S. Treasury Market?

A Specification Test for Affine Term Structure Models

WP-06-15

Torben G. Andersen and Luca Benzoni

Transforming Payment Choices by Doubling Fees on the Illinois Tollway

Gene Amromin, Carrie Jankowski, and Richard D. Porter

WP-06-16

How Did the 2003 Dividend Tax Cut Affect Stock Prices?

WP-06-17

Gene Amromin, Paul Harrison, and Steven Sharpe

Will Writing and Bequest Motives: Early 20th Century Irish Evidence

WP-06-18

Leslie McGranahan

How Professional Forecasters View Shocks to GDP

WP-06-19

Spencer D. Krane

Evolving Agglomeration in the U.S. auto supplier industry

WP-06-20

Thomas Klier and Daniel P. McMillen

Mortality, Mass-Layoffs, and Career Outcomes: An Analysis using Administrative Data

WP-06-21

Daniel Sullivan and Till von Wachter 


\section{Working Paper Series (continued)}

The Agreement on Subsidies and Countervailing Measures:

Tying One's Hand through the WTO.

WP-06-22

Meredith A. Crowley

How Did Schooling Laws Improve Long-Term Health and Lower Mortality?

WP-06-23

Bhashkar Mazumder

Manufacturing Plants’ Use of Temporary Workers: An Analysis Using Census Micro Data

WP-06-24

Yukako Ono and Daniel Sullivan

What Can We Learn about Financial Access from U.S. Immigrants?

WP-06-25

Una Okonkwo Osili and Anna Paulson

Bank Imputed Interest Rates: Unbiased Estimates of Offered Rates?

WP-06-26

Evren Ors and Tara Rice

Welfare Implications of the Transition to High Household Debt

WP-06-27

Jeffrey R. Campbell and Zvi Hercowitz

Last-In First-Out Oligopoly Dynamics

WP-06-28

Jaap H. Abbring and Jeffrey R. Campbell

Oligopoly Dynamics with Barriers to Entry

WP-06-29

Jaap H. Abbring and Jeffrey R. Campbell

Risk Taking and the Quality of Informal Insurance: Gambling and Remittances in Thailand Douglas L. Miller and Anna L. Paulson

WP-07-01

Fast Micro and Slow Macro: Can Aggregation Explain the Persistence of Inflation?

Filippo Altissimo, Benoît Mojon, and Paolo Zaffaroni

WP-07-02

Assessing a Decade of Interstate Bank Branching

WP-07-03

Christian Johnson and Tara Rice

Debit Card and Cash Usage: A Cross-Country Analysis

WP-07-04 Gene Amromin and Sujit Chakravorti 